\title{
CORRIGENDUM
}

\section{Dietary acid-base balance and intake of bone-related nutrients in Cambridge teenagers}

\author{
CJ Prynne, F Ginty, AA Paul, C Bolton-Smith, SJ Stear, SC Jones and A Prentice
}

European Journal of Clinical Nutrition (2004) 58, 1558. doi:10.1038/sj.ejcn.1602069

Correction to: European Journal of Clinical Nutrition (2004) 58, 1462-1471. doi:10.1038/sj.ejcn.1602006

Following the online publication of the above paper, the authors have identified an error in Table 4 and would like to apologise for any confusion this might have caused. The correct table is reproduced below. Please note that the paper this Corrigendum is relating to is published in print in this issue of EJCN 58, 1462-1471.

Table 4 Mean estimates of dietary acid-base balance of boys $(n=111)$ and girls $(n=101)$

\begin{tabular}{lccc}
\hline & $\begin{array}{c}\text { Boys } \\
\text { Mean (s.d.) }\end{array}$ & $\begin{array}{c}\text { Girls } \\
\text { Mean (s.d.) }\end{array}$ & $P$ \\
\hline $\mathrm{NAE}_{\text {ind }}$ (mEq/day) & $67.8(15.7)$ & $53.8(11.6)$ & $<0.001$ \\
Protein/potassium ratio & $1.08(0.19)$ & $1.00(0.17)$ & $<0.001$ \\
(g/mEq/day) & & & \\
\hline
\end{tabular}

$\mathrm{NAE}_{\text {ind }}=$ Net Acid Excretion estimated indirectly (Remer \& Manz, 1994). 